FORSKNING

Denne artikkelen finnes også i engelsk utgave. Publiserings dato: 26.02.2018

\title{
Preoperativ oppvarming med varmluftsteppe forebygger hypotermi under operasjon
}

\section{Bjørg Eli Broback}

Anestesisykepleier

Stavanger universitetssjukehus

\section{Gjertrud Øvsthus Skutle}

Anestesisykepleier

Voss sjukehus

\section{Elin Dysvik}

\section{Professor}

Institutt for helsefag, Universitetet i Stavanger

\section{Arild Eskeland}

Universitetslektor

Institutt for helsefag, Universitetet i Stavanger

$$
\text { Systematisk oversikt }
$$

$$
\text { Anestesisykepleie }
$$

Utilsiktet hypotermi

Sykepleien Forskning 201813 (65819) (e-65819)

DOI: 10.4220/Sykepleienf.2018.65819

\section{Sammendrag}


Bakgrunn: Operasjonspasienten utsettes for varmetap. Det er viktig å forebygge utilsiktet hypotermi hos operasjonspasienten for å unngå unødige komplikasjoner som $\varnothing \mathrm{kt}$ oksygenbehov, $\varnothing \mathrm{kt}$ infeksjonsrisiko og kardiovaskulære problemer.

Hensikt: $\AA$ frembringe ny kunnskap om hvilken effekt det har å bruke varmluftsteppe for å forebygge utilsiktet hypotermi hos elektive operasjonspasienter i generell anestesi.

Metode: Vi gjennomførte et oppdatert systematisk artikkels $\varnothing \mathrm{k}$ i databasene CINAHL (EBSCO), Embase (Ovid), Cochrane Register of Controlled Trials (Wiley), MEDLINE (Ovid) og ScienceDirect fra januar 2011 til februar 2016 for å komplementere de eksisterende systematiske oversiktene. Randomiserte, kontrollerte studier publisert på engelsk og skandinavisk ble inkludert. Vi vurderte studiene kritisk med tanke på risiko for systematiske skjevheter og presenterte samlete funn i en narrativ analyse.

Resultat: Vi identifiserte 624 referanser og inkluderte totalt 10 artikler i analysen. Åtte av ti studier viser positiv effekt av tiltaket med preoperativ oppvarming med varmluftsteppe. Flertallet av disse studiene kan vise til statistisk signifikante resultater og har lav risiko for skjevheter.

Konklusjon: Resultatene indikerer at preoperativ oppvarming med varmluftsteppe har signifikant effekt på å forebygge utilsiktet hypotermi hos voksne elektive operasjonspasienter i generell anestesi. Oppvarming av pasientene kan med fordel fortsette peroperativt.

Hypotermi er en komplikasjon som ofte forekommer i forbindelse med kirurgi og kan være utfordrende å forebygge. Definisjonen på hypotermi er kjernetemperatur under 36, o grader. Pasienter som skal gjennomgå kirurgiske inngrep i generell anestesi, får som regel redusert kroppstemperaturen med 2-3 grader dersom forebyggende tiltak ikke iverksettes (1).

Prognostiske faktorer som alder, kroppsmasseindeks (KMI), grad av sykelighet (American Society of Anesthesiologist (ASA)-klassifikasjon) og operasjonstid påvirker i hvor stor grad pasienten er utsatt for hypotermi. 
Når pasienten ankommer operasjonsstuen, utsettes vedkommende med én gang for varmetap. Årsakene til varmetapet er lav temperatur på operasjonsstuen, avkledning og desinfeksjon av operasjonsområdet med kalde væsker.

Infusjon av kjølige væsker og forflytning fra sengen til operasjonsbordet utsetter pasienten for ytterligere varmetap. Ved innledning av anestesi reagerer kroppen med vasodilatasjon, og den naturlige termoreguleringen vil ikke fungere som normalt. Under operasjonen ligger pasienten stille på operasjonsbordet, og varmeproduksjonen foregår dermed ved hjelp av basalstoffskiftet.

Pasienten klarer heller ikke å kompensere for varmetapet med skjelving på grunn av muskelblokade. Kroppen omfordeler varme fra sentrale til perifere deler av kroppen, slik at kjernetemperaturen faller. Operasjonspasienten taper også varme gjennom fordamping fra hud, operasjonssår og luftveier $(2,3)$.

\section{Felles ansvar for å forebygge hypotermi}

Hele operasjonsteamet er opptatt av å forebygge hypotermi, og det er et felles ansvar. Dette ansvaret fremkommer som et eget punkt i sjekklisten for trygg kirurgi. Sjekklisten har som formål å hindre at unødvendige komplikasjoner og skader oppstår under kirurgi (4).

\section{«Anestesisykepleiere har et særskilt ansvar med tanke på å observere og måle temperatur samt iverksette tiltak for å forebygge hypotermi.»}

Dersom operasjonspasienten blir hypoterm, øker risikoen for ulike anestesirelaterte komplikasjoner som $\varnothing \mathrm{kt}$ oksygenbehov, blødningsfare, infeksjonsrisiko og unødig ubehag under og etter operasjonen. Samtidig kan hypotermi forlenge virkningen av anestesimidlene (3). Ifølge Bozimowski (2) kan hypotermi også føre til at uønskete kardiovaskulære hendelser oppstår. 
Anestesisykepleiere har et særskilt ansvar med tanke på å observere og måle temperatur samt iverksette tiltak for å forebygge hypotermi (5). Anestesisykepleierens ansvar for å forebygge komplikasjoner og iverksette tiltak pre-, per- og postanestetisk er stadfestet i funksjonsbeskrivelsen for anestesisykepleiere (6).

\section{Preoperativ oppvarming}

Preoperativ oppvarming defineres som oppvarming av pasientens perifere vev eller hudoverflate ved hjelp av ulike oppvarmingsmetoder i forkant av operasjonen. Denne oppvarmingen medvirker til temperaturstigning perifert. Dermed reduseres varmetapet som følge av at varmen omfordeles fra kjernen til perifere deler av kroppen (7).

Forskningslitteraturen viser at aktiv oppvarming med varmluftsteppe er den mest effektive oppvarmingsmetoden for å forebygge utilsiktet hypotermi hos operasjonspasienten. Når varmluftsteppet brukes, blåses varm luft fra en varmekilde inn i et tynt engangsteppe som legges over pasientens kropp (8).

Vi utførte forberedende $\varsigma \varnothing \mathrm{k}$ i aktuelle databaser i forkant av litteraturs $\varnothing$ ket vårt. I det forberedende søket fant vi en systematisk oversikt fra 2012 og en oversiktsartikkel fra 2013. Disse artiklene indikerer at aktiv preoperativ oppvarming av operasjonspasienten kan forebygge utilsiktet hypotermi hos operasjonspasienten $(9,10)$.

Den metodiske kvaliteten i studiene som ble inkludert i disse artiklene, er likevel vurdert til å være varierende, samtidig oppgis det usikre konklusjoner. Disse oversiktsartiklene omhandler også ulike typer oppvarmingsmetoder for preoperativ oppvarming, og anestesimetode varierer på tvers av studiene. 


\section{Hensikt med studien}

Hensikten med studien vår var å frembringe ny kunnskap om effekten av å bruke varmluftsteppe til å forebygge utilsiktet hypotermi under operasjon.

Vi valgte følgende problemstilling:

«Hvilken effekt kan preoperativ oppvarming med varmluftsteppe ha på å forebygge utilsiktet hypotermi hos elektive operasjonspasienter i generell anestesi?»

\section{Metode}

Denne artikkelen er en systematisk litteraturoversikt en systematisk kunnskapsoppsummering av relevante forskningsartikler som kan gi svar på problemstillingen. Systematiske litteraturoversikter blir ofte regnet som kjernen av kunnskapsbasert praksis og kan bidra til konklusjoner som kan være nyttige i praksis (11).

F $\varnothing \mathrm{r}$ vi satte i gang med litteraturs $\varnothing \mathrm{k}$ og litteraturgjennomgang, laget vi en metodisk plan for hvordan vi skulle utarbeide studien vår. Denne planen er beskrevet i en egen protokoll, en prosjektplan. Protokollen kan utleveres ved å ta kontakt med førsteforfatteren. For å kvalitetssikre rapporteringen av vår systematiske oversikt har vi gjennom hele utarbeidelsen anvendt PRISMA-sjekkliste (12).

I 2012 og 2013 ble det publisert en systematisk oversiktsartikkel og en oversiktsartikkel der formålet var å klargjøre om preoperativ oppvarming kan forebygge utilsiktet hypotermi hos operasjonspasienten $(9,10)$. Etter at vi hadde vurdert artiklene kritisk med PRISMA-sjekkliste, valgte vi de Brito Poveda og medarbeidere (9) fremfor Roberson og medarbeidere (10). 
Grunnen er at studien til de Brito Poveda og medarbeidere (9) er en systematisk oversikt og bygger på randomiserte, kontrollerte studier (randomised controlled trial, RCT). Vi mener det er nødvendig å oppdatere de Brito Poveda og medarbeidere (9) fordi de anvender kvalitetsverktøyet Jadad og har en usikker konklusjon.

Jadad er et kvalitetsverktøy The Cochrane Collaboration fraråder å bruke. Begrunnelsen er at tallskalaer ikke blir ansett som et pålitelig verktøy for å måle validitet, og at det ikke kommer tydelig frem hva som ligger til grunn for vurderingen. I tillegg unnlater verktøyet å se på om randomiseringsprosessen er skjult på en hensiktsmessig måte (13).

\section{Artikkelsøk og søkeord}

I studien til de Brito Poveda og medarbeidere (9) er det systematiske artikkels $\varnothing$ ket gjennomf $\varnothing$ rt i flere databaser, og de benyttet ulike variasjoner av både emne- og tekstord (se vedlegg). Søkestreng er ikke oppgitt. Inklusjonskriteriene for denne systematiske oversikten var RCT-studier publisert mellom januar 1990 og november 2011, som testet hvorvidt preoperativ oppvarming kan forebygge hypotermi hos elektive operasjonspasienter over 18 år.

Språkavgrensingen var engelsk, spansk og portugisisk, og totalt inkluderte de 14 artikler. På bakgrunn av ovennevnte betraktninger valgte vi å utføre et oppdatert artikkelsøk basert på den systematiske oversiktsartikkelen som ble utarbeidet av de Brito Poveda og medarbeidere (9).

I forkant av artikkelsøket utformet vi en søkestrategi basert på PICO-skjema samt søkeord fra studien til de Brito Poveda og medarbeidere, som vi valgte å oppdatere (9). For å strukturere og kombinere søkeordene riktig er PICO-skjema et godt hjelpemiddel (14). Emne- og tekstord i kombinasjoner for populasjon, intervensjon og utfallsmål anvendte vi i nytt, oppdatert artikkels $\varnothing \mathrm{k}$. 
Vi brukte de samme søkeordene som de Brito Poveda og medarbeidere (9), men vi la også til nye, relevante søkeord. Det oppdaterte artikkels $\varnothing$ ket foregikk i perioden oktober 2015 til februar 2016 i ulike databaser (se vedlegg). Da vi bygger videre på et artikkelsøk andre har utført, søkte vi etter studier publisert fra januar 2011 til februar 2016.

\section{Individuelle søk og siteringssøk}

I tillegg utførte vi individuelle s $\varnothing \mathrm{k}$ i inkluderte artiklers referanselister samt siteringss $\varnothing \mathrm{k}$. Inklusjonskriteriene for den systematiske oversikten vår er følgende: RCT publisert på engelsk eller skandinavisk, som testet effekten av preoperativ oppvarming med varmluftsteppe for å forebygge utilsiktet hypotermi.

Studiene omhandlet voksne operasjonspasienter mellom 18 og 85 år som skulle gjennomgå elektive kirurgiske inngrep i generell anestesi. Vi ekskluderte studier der det ble anvendt regional anestesi eller andre oppvarmingsmetoder enn varmluftsteppe. Utfallsmålene vi var ute etter, var pasientenes kjernetemperaturer og tilfeller med opprettholdt normotermi, altså en kjernetemperatur over 36 grader.

\section{Seleksjon og vurdering}

To forfattere utførte seleksjonsprosessen uavhengig av hverandre. I første omgang vurderte vi tittel og sammendrag opp mot inklusjons- og eksklusjonskriteriene. Videre innhentet vi alle potensielt relevante artikler i fulltekst, og til sist vurderte vi om vi skulle inkludere eller ekskludere dem. De to forfatterne utførte i tillegg dataekstraksjon individuelt og samlet til slutt relevante data i to beskrivende tabeller (tabell 1 og 2 under Resultater). 
Først vurderte vi de inkluderte studiene kritisk ved hjelp av sjekklisten for RCT-studier, som er utarbeidet av Nasjonalt kunnskapssenter for helsetjenesten (15). Deretter vurderte vi risikoen for systematiske skjevheter ved hjelp av validitetsverktøyet The Cochrane Collaboration's tool for assessing risk of bias (RoB). Sju hovedpunkter gjenspeiler ulike trekk ved studien som kan gi risiko for systematiske skjevheter (13).

To forfattere vurderte uavhengig av hverandre hvor stor risikoen for systematiske skjevheter var i de inkluderte studiene. De ulike punktene i validitetsverkt $\varnothing$ yet (RoB) ble gradert til lav, høy eller uklar risiko for systematiske skjevheter. Basert på disse vurderingene fastsatte vi en samlet vurdering av hele studien. Vurderingene ble så lagt inn i dataprogrammet RevMan, som fremstiller oppsummerende tabeller over risikoen for systematisk skjevheter (13).

I prosjektplanen hadde vi først planlagt å utføre en metaanalyse. Etter litteraturs $\varnothing$ ket vurderte vi den imidlertid som uegnet fordi det var for stor heterogenitet i de inkluderte studiene. Årsaken var sprikende intervensjonsvarighet, varmestyrke, benyttet måleverktøy og utfallsmål mellom studiene. For å gi en samlet beskrivelse av resultatene utførte vi derfor en narrativ analyse.

Begge forfatterne leste grundig gjennom inkluderte artikler og klassifiserte dem i to kategorier med undertemaer. Dermed fikk vi en strukturert beskrivelse og sammenlikning av resultatene til de inkluderte studiene.

\section{Resultater}


Vi indentifiserte i alt 624 referanser gjennom vårt systematiske artikkels $\varnothing \mathrm{k}$. Av disse skrev vi ut $14 \mathrm{og}$ leste dem grundig gjennom. Etter å ha vurdert artiklene i henhold til våre inklusjons- og eksklusjonskriterier ekskluderte vi ti artikler (figur 1). Fire nye studier ble inkludert fra et nytt, oppdatert artikkels $\varnothing \mathrm{k}$ (16-19). Vi vurderte også alle artiklene til de Brito Poveda og medarbeidere (9) for inklusjon og eksklusjon, og vi inkluderte seks studier (20-25). Totalt satt vi igjen med ti artikler som var aktuelle for videre analyse.

Figur 1: Flytdiagram for utvelgelse av studier

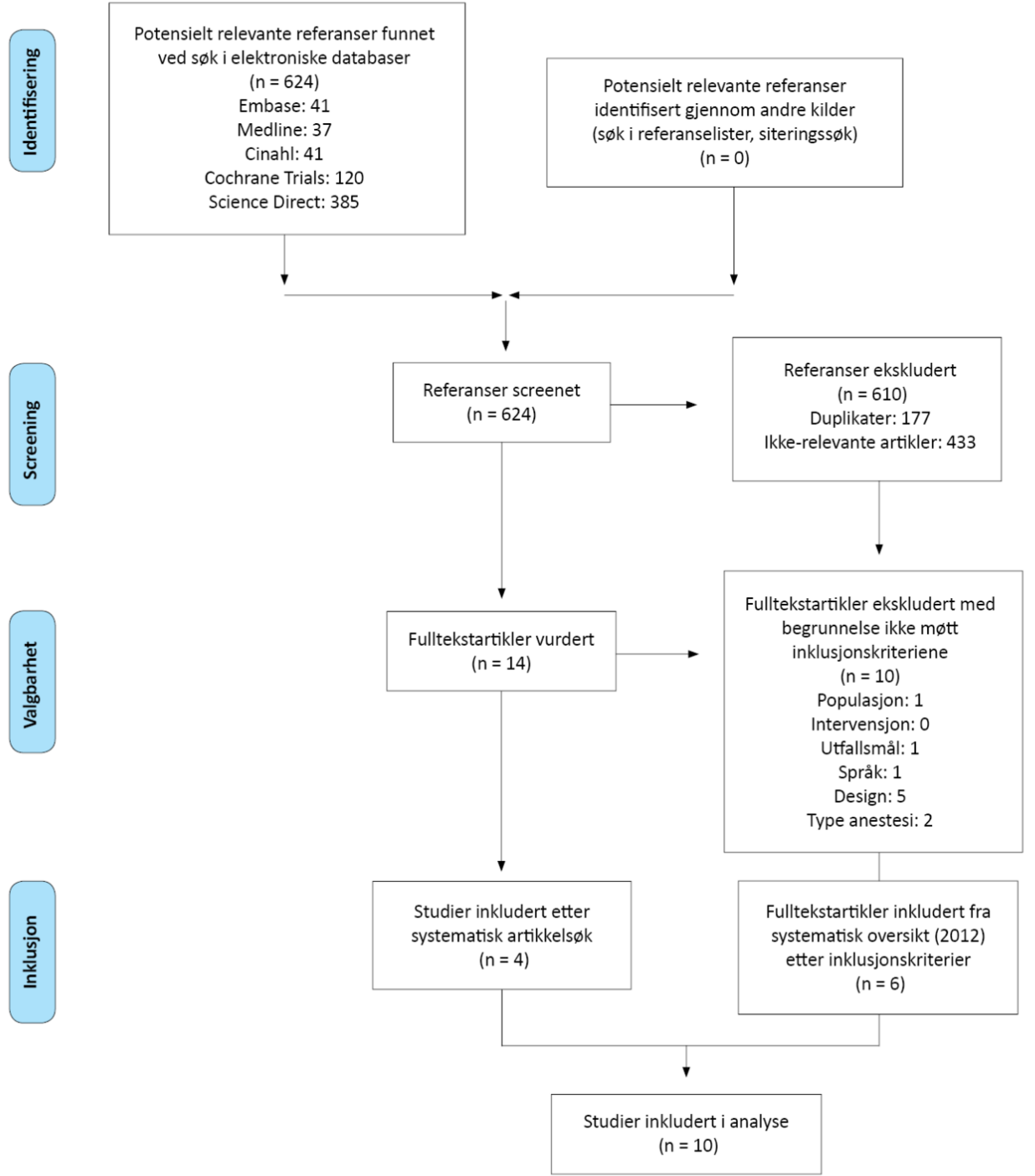

Søk mellom 2011-2016 på bakgrunn av artikkelsøk i systematisk oversikt fra 2012. 
Antall deltakere i studiene varierte fra 27-383,

gjennomsnittsalderen var fra 40-60 år, og

gjennomsnittlig KMI for deltakerne var 25. Alle

deltakerne gjennomgikk elektive inngrep i generell

anestesi, og flertallet hadde en ASA-klassifikasjon $\leq$ III.

Hvilken ASA-klassifikasjon pasientene har, sier noe om

graden av sykelighet og gjenspeiler pasientens

fysiologiske tilstand i forkant av anestesi (2). I tabell 1

presenterer vi særtrekk ved de inkluderte studiene.

Tabell 1: Særtrekk ved inkluderte RCT-studier

\begin{tabular}{|c|c|c|c|c|c|}
\hline $\begin{array}{l}\text { Studie, år, land, } \\
\text { (referanse) }\end{array}$ & $\begin{array}{l}\text { Populasjon } \\
\text { (antall deltakere, beskrivelse) }\end{array}$ & Utfallsmål & Type kirurgi & $\begin{array}{l}\text { Alder (SD) i år / } \\
\text { KMI (SD) i kg/m2 }\end{array}$ & RoB-skår \\
\hline $\begin{array}{l}\text { Fettes S, Mulvaine M., Van } \\
\text { Doren E, 2013, USA (16) }\end{array}$ & $\begin{array}{l}n=128 \text { (18-85 år) } \\
\text { engelsktalende operasjon- } \\
\text { spasienter med ASA 1-3 }\end{array}$ & $\begin{array}{l}\text { Primære: kroppstemperatur pre-, } \\
\text { per- og postoperativt } \\
\text { Sekundære: liggetid på postopera- } \\
\text { tiv avdeling }\end{array}$ & $\begin{array}{l}\text { Eksplorativ laparotomi, } \\
\text { colorektal kirurgi, pro- } \\
\text { tesekirurgi, spinal- og } \\
\text { brystkirurgi, hysterektomi } \\
\text { og robotassistert kirurgi i } \\
\text { urinveiene }\end{array}$ & $58,4 / 32,3$ & $H \varnothing y$ \\
\hline $\begin{array}{l}\text { Perl T, Peichl LH, Reyntjens } \\
\text { K, Deblaere I, Zaballos JM, } \\
\text { Brauer A, 2014, Tyskland } \\
\text { (17) }\end{array}$ & $\begin{array}{l}\mathrm{n}=68 \text { (18-70 år) } \\
\text { operasjonspasienter som skal } \\
\text { gjennomgå elektiv kirurgi med } \\
\text { ASA 1-3, KMI 20-30 }\end{array}$ & $\begin{array}{l}\text { Primære: kjernetemperatur og } \\
\text { tilfeller av hypotermi } \\
\text { Sekundære: kjernetemperatur } \\
\text { på postoperativ avdeling, termisk } \\
\text { komfort og skjelving }\end{array}$ & $\begin{array}{l}\text { Abdominal kirurgi, under- } \\
\text { og over-ekstremiteter, } \\
\text { torakskirurgi og hode- og } \\
\text { nakkekirurgi }\end{array}$ & $\begin{array}{l}43(+/-16) / 25 \\
(+/-3)\end{array}$ & Lav \\
\hline $\begin{array}{l}\text { Horn EP, Bein B, Bohm R, } \\
\text { Stenfath M, Sahili N, Hock- } \\
\text { er J, 2012, Tyskland (18) }\end{array}$ & $\begin{array}{l}n=200 \text { (>18 år) } \\
\text { operasjonspasienter som skal } \\
\text { gjennomgå elektiv kirurgi med } \\
\text { operasjonstid 30-90 min., ASA } \\
1-3\end{array}$ & $\begin{array}{l}\text { Primære: kjernetemperatur pre-, } \\
\text { per- og postoperativt samt tilfeller } \\
\text { av hypotermi } \\
\text { Sekundære: grad av skjelving og } \\
\text { termisk komfort }\end{array}$ & $\begin{array}{l}\text { Laparoskopier, toraks- } \\
\text { kirurgi, ortopedi og } \\
\varnothing \mathrm{NH}-\text { kirurgi }\end{array}$ & $54 / 26,7$ & Lav \\
\hline $\begin{array}{l}\text { Nicholson M, 2013, USA } \\
\text { (19) }\end{array}$ & $\begin{array}{l}\mathrm{n}=66 \text { (>18 år) } \\
\text { operasjonspasienter som skal } \\
\text { gjennomgå elektive inngrep } \\
\text { med preoperativ oppvarming > } \\
30 \text { min. }\end{array}$ & $\begin{array}{l}\text { Primære: kroppstemperatur pre-, } \\
\text { per- og postoperativt }\end{array}$ & Colorektale inngrep & $\begin{array}{l}\text { Variasjonabredde } \\
\text { fra } 18-89 / 18,5 \\
>30\end{array}$ & $H ø y$ \\
\hline $\begin{array}{l}\text { Camus Y, Delva E, Sessler D, } \\
\text { Lienhart A, 1995, USA (20) }\end{array}$ & $\begin{array}{l}n=16 \text { (>18 år) } \\
\text { operasjonspasienter som skal } \\
\text { gjennomgå elektiv kirurgi med } \\
\text { ASA 1-2 }\end{array}$ & $\begin{array}{l}\text { Primære: kjernetemperatur pre-, } \\
\text { per- og postoperativt } \\
\text { Sekundære: hudoverflatetempera- } \\
\text { turer og postoperativ skjelving }\end{array}$ & $\begin{array}{l}\text { Laparoskopisk kole- } \\
\text { cystektomi }\end{array}$ & $46(+/-4) / 24,8$ & Lav \\
\hline $\begin{array}{l}\text { Fossum S, Hays J, Henson } \\
\text { MM, 2001, USA (21) }\end{array}$ & $\begin{array}{l}n=100 \text { (>18 år) } \\
\text { operasjonspasienter med ASA } \\
1-3 \text { og operasjonstid } 60-180 \\
\text { min. }\end{array}$ & $\begin{array}{l}\text { Primære: kjernetemperatur pre-, } \\
\text { per- og postoperativt } \\
\text { Sekundære: termisk komfort, } \\
\text { postoperativ skjelving, postoper- } \\
\text { ativ kvalme/oppkast og behov for } \\
\text { smertestillende }\end{array}$ & $\begin{array}{l}\text { Gynekologiske, ortope- } \\
\text { diske og urologiske }\end{array}$ & $\begin{array}{l}47(+/-16) / \text { ikke } \\
\text { oppgitt }\end{array}$ & $H ø y$ \\
\hline $\begin{array}{l}\text { Kim JY, Shinn H, Oh YJ, } \\
\text { Hong YW, Kwak HJ, Kwak } \\
\text { YL, 2006, Korea (22) }\end{array}$ & $\begin{array}{l}n=40 \text { ( }>18 \text { år) } \\
\text { operasjonspasienter som skal } \\
\text { gjennomgå elektiv kirurgi }\end{array}$ & $\begin{array}{l}\text { Primære: hud- og kjernetempera- } \\
\text { tur pre-, per- og postoperativt }\end{array}$ & $\begin{array}{l}\text { Hjertearterie bypass- } \\
\text { operasjoner }\end{array}$ & $\begin{array}{l}64(+/-8) / \text { ikke } \\
\text { oppgitt }\end{array}$ & Uklar \\
\hline $\begin{array}{l}\text { Andrzejowski J, Hoyle J, } \\
\text { Turnbull D, 2008, England } \\
\text { (23) }\end{array}$ & $\begin{array}{l}n=76 \text { (>18 år) } \\
\text { elektive operasjonspasienter } \\
\text { med ASA } 1 \text { eller } 2\end{array}$ & $\begin{array}{l}\text { Primære: kjernetemperatur og } \\
\text { tilfeller av utilsiktet hypotermi } \\
\text { Sekundære: kvalme, oppkast og } \\
\text { skjelving }\end{array}$ & Spinalkanalkirurgi & $54 / 28,4(+/-3,8)$ & $H \varnothing y$ \\
\hline $\begin{array}{l}\text { De Witte JL, Demeyer } \\
\text { C, Vandemaele E, 2010, } \\
\text { Belgia (24) }\end{array}$ & $\begin{array}{l}n=27 \text { (>18 år) } \\
\text { operasjonspasienter som skal } \\
\text { gjennomgå elektiv kirurgi med } \\
\text { KMI 18-28 }\end{array}$ & $\begin{array}{l}\text { Primære: kjerne-, hud- og kro- } \\
\text { ppstemperaturer } \\
\text { Sekundære: svetting }\end{array}$ & $\begin{array}{l}\text { Laparoskopisk colorektal } \\
\text { kirurgi }\end{array}$ & $\begin{array}{l}66(+/-12) / 23 \\
(+/-2)\end{array}$ & Lav \\
\hline $\begin{array}{l}\text { Smith C, Sidhu R, Lucas L, } \\
\text { Mehta D, Pinchak A, 2006, } \\
\text { USA (25) }\end{array}$ & $\begin{array}{l}n=383 \text { (18-85 år) } \\
\text { elektive operasjonspasienter } \\
\text { med ASA 1-2 og operasjonstid } \\
>30 \text { min. }\end{array}$ & $\begin{array}{l}\text { Primære: kjernetemperatur } \\
\text { Sekundære: vitale tegn, tilfeller } \\
\text { og grad av skjelving, medikament- } \\
\text { forbruk, bruk av varmeutstyr } \\
\text { postoperativt og liggetid på } \\
\text { postoperativ avdeling }\end{array}$ & $\begin{array}{l}\text { Dagkirurgi innen gyne- } \\
\text { kologi, ortopedi eller } \\
\text { urologi }\end{array}$ & $40(+/-13) / 28,3$ & Lav \\
\hline
\end{tabular}

RCT = Randomized Controlled Trial

$A S A=$ American Society of Anesthesiologists (system for gradering av risiko i forbindelse med anestesi)

$\mathrm{KMI}=$ kroppsmasseindeks

$\mathrm{SD}=$ standardavvik

RoB-skår $=$ risiko for skjevheter

$\varnothing \mathrm{NH}$-kirurgi = $\varnothing$ re-nese-hals-kirurg

Alder og KMI blir oppgitt i den preoppvarmete gruppen. Verdiene er oppgitt som i artiklene (gjennomsnitt, standardawik og range).

Artikkel nr. 1-4 er fra nytt systematisk artikkelsøk mellom 2011-2016, artikkel nr. 5-10 er fra de Brito Poveda og medarbeidere (2012). 
Alle inkluderte studier testet effekten av preoperativ oppvarming med varmluftsteppe. Vi klassifiserte studiene i to kategorier: studier som testet preoperativ oppvarming, og studier som testet preoperativ oppvarming der aktiv oppvarming fortsatte peroperativt. Tabell 2 beskriver intervensjonen nærmere.

Tabell 2: Beskrivelse av intervensjonen

\begin{tabular}{|c|c|c|c|c|c|c|c|c|}
\hline $\begin{array}{l}\text { Studie, år } \\
\text { (referanse) }\end{array}$ & Type intervensjon & $\begin{array}{l}\text { Sammenlikning } \\
\text { (kontrollgruppe) }\end{array}$ & $\begin{array}{l}\text { Varighet } \\
\text { intervensjon }\end{array}$ & $\begin{array}{l}\text { Varme- } \\
\text { styrke }\end{array}$ & Måleverktøy & $\begin{array}{l}\text { Måletidspunkt } \\
\text { av temperatur }\end{array}$ & $\begin{array}{l}\text { Rom } \\
\text { Temperatur }\end{array}$ & Resultat \\
\hline $\begin{array}{l}\text { Fettes S, Mul- } \\
\text { vaine M, Van } \\
\text { Doren E, } 2013 \\
(16)\end{array}$ & $\begin{array}{l}\text { Preoperativ + peroperativ } \\
\text { oppvarming med varmlu- } \\
\text { ftsteppe }\end{array}$ & $\begin{array}{l}\text { Varme } \\
\text { bomullstepper } \\
\text { preoperativt }\end{array}$ & Ca. $60 \mathrm{~min}$. & $\begin{array}{l}\text { Medium } \\
\text { styrke } \\
\text { ( } 37,8 \text { grader) }\end{array}$ & $\begin{array}{l}\text { Infrarødt tem- } \\
\text { poralt tinning- } \\
\text { skanne-ter- } \\
\text { mometer }\end{array}$ & $\begin{array}{l}\text { Pre-, per- og } \\
\text { postoperativt }\end{array}$ & Ikke oppgitt & $\begin{array}{l}\text { Intervensjonen } \\
\text { hadde ikke effekt } \\
\text { på postoperative } \\
\text { kroppstemperatur }\end{array}$ \\
\hline $\begin{array}{l}\text { Perl T, Peichl } \\
\text { LH, Reyntjens } \\
\text { K, Deblaere I, } \\
\text { Zaballos JM, } \\
\text { Brauer A, 2014 } \\
\text { (17) }\end{array}$ & $\begin{array}{l}\text { Preoperativ + peroperativ } \\
\text { oppvarming med varmlu- } \\
\text { ftsteppe }\end{array}$ & $\begin{array}{l}\text { 1. Sykehus- } \\
\text { dyne } \\
\text { 2. Varmedrakt } \\
\text { (uten varmluft) }\end{array}$ & $30-60 \mathrm{~min}$. & $\begin{array}{l}\text { Maks. styrke } \\
\text { peroperativt }\end{array}$ & $\begin{array}{l}\text { Sublingualt } \\
\text { temperatur- } \\
\text { mál pre- og } \\
\text { postoperativt, } \\
\text { og øsofagealt } \\
\text { temperaturmål } \\
\text { peroperativt }\end{array}$ & $\begin{array}{l}\text { Preoperativt på } \\
\text { sengepost og før } \\
\text { anestesiinnled- } \\
\text { ning, hvert } 10 \\
\text { min. postopera- } \\
\text { tivt. } \\
\text { Hvert } 15 \text {. min. } \\
\text { peroperativt }\end{array}$ & $\begin{array}{l}20,6 \\
(+/-0,9)\end{array}$ & $\begin{array}{l}\text { Intervensjonen } \\
\text { fører til høyere } \\
\text { kjernetemperaturer } \\
\text { under anestesi og } \\
\text { ved operasjonsslutt }\end{array}$ \\
\hline $\begin{array}{l}\text { Horn EP, Bein B, } \\
\text { Bohm R, Sten- } \\
\text { fath M, Sahili N, } \\
\text { Hocker J, 2012 } \\
\text { (18) }\end{array}$ & $\begin{array}{l}\text { Preoperativ oppvarming } \\
\text { med varmluftsteppe }+ \text { per- } \\
\text { operativ oppvarming med } \\
\text { bomullsteppe. } \\
\text { Varmluftsteppe på overk- } \\
\text { ropp hvis temp }<36 \text { grader. }\end{array}$ & $\begin{array}{l}\text { Passiv / ingen } \\
\text { preoperativ op- } \\
\text { pvarming }\end{array}$ & $\begin{array}{l}3 \text { grupper: } \\
10,20 \text { og } 30 \\
\text { min. }\end{array}$ & $\begin{array}{l}\text { Høy styrke } \\
\text { (44 grader) }\end{array}$ & $\begin{array}{l}\varnothing \text { retermome- } \\
\text { ter med aurale } \\
\text { prober }\end{array}$ & $\begin{array}{l}\text { Målt kontinuerlig } \\
\text { fra ankomst pre- } \\
\text { operativ avd. til } \\
60 \text { minutter etter } \\
\text { ankomst postop- } \\
\text { erativ avd. }\end{array}$ & $\begin{array}{l}22,9(+/- \\
-0,7)\end{array}$ & $\begin{array}{l}\text { Intervensjonen i } \\
\text { perioder på 10, } 20 \\
\text { eller } 30 \text { minutter } \\
\text { reduserte betydelig } \\
\text { risikoen for peri- } \\
\text { operativ hypotermi } \\
\text { og postoperativ } \\
\text { skjelving }\end{array}$ \\
\hline $\begin{array}{l}\text { Nicholson M, } \\
2013(19)\end{array}$ & $\begin{array}{l}\text { Preoperativ + peroperativ } \\
\text { oppvarming med varmlu- } \\
\text { ftsteppe }\end{array}$ & Bomullsteppe & $\begin{array}{l}75 \mathrm{~min} .(+/- \\
56 \mathrm{~min} .)\end{array}$ & Ikke oppgitt & $\begin{array}{l}\text { Elektronisk oralt } \\
\text { termometer } \\
\text { pre- og postop- } \\
\text { erativt. } \\
\text { Øsofagealt, rek- } \\
\text { talt eller tem- } \\
\text { peratur mált } \\
\text { i urinkateter } \\
\text { peroperativt }\end{array}$ & $\begin{array}{l}\text { Preoperativt } \\
\text { etter } 30 \text { min. op- } \\
\text { pvarming, etter } \\
\text { anestesiinnled- } \\
\text { ning og hvert } 15 \text {. } \\
\text { min. postoper- } \\
\text { ativt }\end{array}$ & 19,9 & $\begin{array}{l}\text { Intervensjonen re- } \\
\text { duserte ikke tilfeller } \\
\text { av utilsiktet hypo- } \\
\text { termi }\end{array}$ \\
\hline $\begin{array}{l}\text { Camus Y, Del- } \\
\text { va E, Sessler } \\
\text { D, Lienhart A, } \\
1995(20)\end{array}$ & $\begin{array}{l}\text { Preoperativ oppvarming } \\
\text { med varmluftsteppe }\end{array}$ & Ullteppe & $\begin{array}{l}61 \text { min. } \\
(+/-1 \text { min. })\end{array}$ & $\begin{array}{l}\text { Høy styrke } \\
\text { (41 grader) }\end{array}$ & $\begin{array}{l}\text { Øretermometer } \\
\text { koplet til aurale } \\
\text { prober og elek- } \\
\text { tronisk måle- } \\
\text { instrument med } \\
\text { prober koplet til } \\
\text { kroppen }\end{array}$ & $\begin{array}{l}\text { Preoperativt } \\
\text { og videre med } \\
\text { intervaller hvert } \\
\text { 15. min. frem til } \\
\text { operasjonsslutt }\end{array}$ & $21(+/-0,1)$ & $\begin{array}{l}\text { Intervensjonen før } \\
\text { anestesiinnledning } \\
\text { har effekt på re- } \\
\text { duksjon av utilisiktet } \\
\text { hypotermi }\end{array}$ \\
\hline $\begin{array}{l}\text { Fossum S, Hays } \\
\text { J, Henson MM, } \\
2001(21)\end{array}$ & $\begin{array}{l}\text { Preoperativ oppvarming } \\
\text { med varmluftsteppe }\end{array}$ & $\begin{array}{l}\text { Varmt } \\
\text { bomullsteppe }\end{array}$ & $45 \mathrm{~min}$. & $\begin{array}{l}\text { Medium } \\
\text { styrke (ca. } \\
38 \text { grader) }\end{array}$ & $\begin{array}{l}\text { Infrarødt } \varnothing \mathrm{re-} \\
\text { termometer }\end{array}$ & $\begin{array}{l}\text { Preoperativt } \\
\text { med intervaller } \\
\text { på } 15 \text { min., rett } \\
\text { før ankomst til } \\
\text { operasjonsstuen } \\
\text { og hvert 15. min. } \\
\text { postoperativt }\end{array}$ & Ikke oppgitt & $\begin{array}{l}\text { Intervensjonen } \\
\text { hadde positiv effekt } \\
\text { på pasientenes } \\
\text { kjernetemperatur } \\
\text { perioperativt }\end{array}$ \\
\hline $\begin{array}{l}\text { Kim JY, Shinn H, } \\
\text { Oh YJ, Hong YW, } \\
\text { Kwak HJ, Kwak } \\
\text { YL, 2006 (22) }\end{array}$ & $\begin{array}{l}\text { Preoperativ oppvarming } \\
\text { med varmluftsteppe }+ \text { per- } \\
\text { operativ oppvarming med } \\
\text { varmemadrass }\end{array}$ & 2 bomullstepper & $\begin{array}{l}49,7 \text { min. } \\
(+/-9,9 \text { min. })\end{array}$ & $\begin{array}{l}\text { Medium } \\
\text { styrke (ca. } \\
40 \text { grader) }\end{array}$ & $\begin{array}{l}\text { Pulmonal- } \\
\text { arteriekateter }\end{array}$ & $\begin{array}{l}\text { Ved ankomst til } \\
\text { operasjonsstuen, } \\
\text { rett før anest- } \\
\text { esiinnledning og } \\
30,60 \text { og } 90 \mathrm{~min} \text {. } \\
\text { etter anestesi- } \\
\text { innledning }\end{array}$ & $\begin{array}{l}20,0 \\
(+l-0,9)\end{array}$ & $\begin{array}{l}\text { Intervensjonen har } \\
\text { effekt og reduserer } \\
\text { tilfeller og graden } \\
\text { av hypotermi. }\end{array}$ \\
\hline $\begin{array}{l}\text { Andrzejowski J, } \\
\text { Hoyle J, Turnbull } \\
\text { D, } 2008 \text { (23) }\end{array}$ & $\begin{array}{l}\text { Preoperativ + peroperativ } \\
\text { oppvarming med varm- } \\
\text { luftsteppe }\end{array}$ & $\begin{array}{l}\text { Teppe uten } \\
\text { varmluft }\end{array}$ & $72 \mathrm{~min}$. & 38 grader & $\begin{array}{l}\text { Infrarødt tem- } \\
\text { poralt tinning- } \\
\text { termometer } \\
\text { pre- og postop- } \\
\text { erativt, } \varnothing \text { sofage- } \\
\text { alt termometer } \\
\text { peroperativt }\end{array}$ & $\begin{array}{l}\text { Preoperativt, } \\
\text { peroperativt } \\
\text { med intervaller } \\
\text { pá } 20 \text { min. }\end{array}$ & $\begin{array}{l}20,7 \\
+/-1,5)\end{array}$ & $\begin{array}{l}60 \text { minutter med } \\
\text { intervensjonen } \\
\text { reduserer tilfeller av } \\
\text { utilsiktet hypotermi }\end{array}$ \\
\hline $\begin{array}{l}\text { De Witte JL, } \\
\text { Demeyer C, } \\
\text { Vandemaele E, } \\
2010 \text { (24) }\end{array}$ & $\begin{array}{l}\text { Preoperativ oppvarming } \\
\text { med varmluftsteppe (eller } \\
\text { karbonfiber) + peroperativ } \\
\text { oppvarming med varm- } \\
\text { luftsteppe }\end{array}$ & Bomullsteppe & $30 \mathrm{~min}$. & 42 grader & $\begin{array}{l}\varnothing \text { retermome- } \\
\text { ter med aurale } \\
\text { prober pre- og } \\
\text { postoperativt, } \\
\varnothing \text { sofagealt } \\
\text { termometer } \\
\text { peroperativt }\end{array}$ & $\begin{array}{l}\text { Kontinuerlig } \\
\text { fra } 10 \text { min før } \\
\text { preoperativ } \\
\text { oppvarming } \\
\text { og frem til } \\
\text { utskrivelse fra } \\
\text { postoperativ } \\
\text { overvâknning }\end{array}$ & $\begin{array}{l}20,0 \\
(+1-0,3)\end{array}$ & $\begin{array}{l}\text { Intervensjonen } \\
\text { burde bli vurdert } \\
\text { som en del av an- } \\
\text { estesihåndteringen } \\
\text { hos pasientene som } \\
\text { har risiko for post- } \\
\text { operativ hypotermi }\end{array}$ \\
\hline $\begin{array}{l}\text { Smith C, Sidhu } \\
\text { R, Lucas L, Meh- } \\
\text { ta D, Pinchak A, } \\
2006 \text { (25) }\end{array}$ & $\begin{array}{l}\text { Preoperativ + peroperativ } \\
\text { oppvarming med varm- } \\
\text { luftsteppe }\end{array}$ & $\begin{array}{l}\text { Vanlig rutine, } \\
\text { ikke spesifisert }\end{array}$ & $\begin{array}{l}42 \mathrm{~min} .(+/- \\
38) \mathrm{min} .\end{array}$ & $\begin{array}{l}\text { Medium } \\
\text { styrke (ca. } \\
40 \text { grader) }\end{array}$ & $\begin{array}{l}\text { Elektronisk } \\
\text { sublingualt } \\
\text { termometer } \\
\text { og } \varnothing \text { sofagealt } \\
\text { termometer }\end{array}$ & $\begin{array}{l}\text { Preoperativt, } \\
\text { hvert 15. min. } \\
\text { peroperativt og } \\
5,30 \text { og } 60 \mathrm{~min} . \\
\text { etter ankomst } \\
\text { postoperativ } \\
\text { overvåkning }\end{array}$ & 21,0 & $\begin{array}{l}\text { Intervensjonen har } \\
\text { effekt på forebyg- } \\
\text { ging av utilsiktet } \\
\text { hypotermi }\end{array}$ \\
\hline
\end{tabular}

Romtemperatur og operasjonstid er oppgitt som gjennomsnitt +/- SD (standardavvik).

De fire første artiklene er fra nytt systematisk artikkelsøk mellom 2011-2016, mens de seks siste artiklene er fra de Brito Poveda og medarbeidere (2012). 


\section{Preoperativ oppvarming med varmluftsteppe}

Tre av studiene benytter bare preoperativ oppvarming med varmluftsteppe for å forebygge utilsiktet hypotermi (20-22). I artikkelen til Camus og medarbeidere (20) viste resultatene at en time preoperativ oppvarming f $\varnothing \mathrm{r}$ anestesiinnledning reduserer utilsiktet hypotermi hos operasjonspasienten. Både Fossum og medarbeidere (21) og Kim og medarbeidere (22), som rapporterer om kortere varighet av intervensjonen, kan vise til resultater som støtter at preoperativ oppvarming reduserer utilsiktet hypotermi.

Alle disse tre studiene viser til signifikante resultater $(\mathrm{p}<0,05)$, men vi har vurdert de to sistnevnte studiene til å inneholde henholdsvis høy og uklar risiko for skjevheter. Denne vurderingen begrunner vi hovedsakelig med at det foreligger en mangelfull beskrivelse av om det ble utført en skjult fordeling av gruppene, samt om utfallsmålene ble blindet for intervensjonen.

Det er heller ikke gjort rede for eventuelle frafall av deltakere. Fossum og medarbeidere (21) har i tillegg anvendt et unøyaktig måleverktøy, noe som var utslagsgivende for vurderingen vår. Camus og medarbeidere (20) har etter vår vurdering lav risiko for skjevheter.

\section{Preoperativ oppvarming kombinert med peroperativ oppvarming med varmluftsteppe}

Sju av studiene benytter preoperativ oppvarming kombinert med peroperativ oppvarming med varmluftsteppe (16-19, 23-25). I studien til Horn og medarbeidere (18) viste resultatene at preoperativ oppvarming i perioder på 10, 20 og 30 minutter reduserte risikoen for perioperativ hypotermi og postoperativ skjelving. Kjernetemperaturen var signifikant høyere i intervensjonsgruppene sammenliknet med kontrollgruppen $(\mathrm{p}<0,05)$. 
Perl og medarbeidere (17) oppga ikke p-verdier, men de konkludere likevel med at kjernetemperaturen var signifikant høyere i intervensjonsgruppen sammenliknet med kontrollgruppene. De Witte og medarbeidere (24) fant ikke signifikante forskjeller i kjernetemperatur mellom kontrollgruppen og intervensjonsgruppen som fikk preoperativ oppvarming med varmluftsteppe. Likevel konkluderer studien med at aktiv preoperativ oppvarming har signifikant effekt.

Etter vår vurdering har disse tre studiene lav risiko for skjevheter. I studiene til Andrzejowski og medarbeidere (23) og Smith og medarbeidere (25) viser resultatene at den gjennomsnittlige kjernetemperaturen i intervensjonsgruppen var signifikant høyere enn hos kontrollgruppen. På grunn av stor variasjon i intervensjonsvarighet har vi likevel vurdert at Andrzejowski og medarbeidere (23) har høy risiko for skjevheter.

I to av studiene viser resultatene at preoperativ oppvarming ikke reduserte tilfeller av utilsiktet hypotermi hos operasjonspasientene $(16,19)$. Ingen av disse studiene viser til signifikante resultater, og risikoen for systematiske skjevheter er høy i begge studiene.

Vi begrunner denne vurderingen i hovedsak med stort frafall av deltakere. I tillegg fikk deltakerne ulik behandling forut for tiltaket som ble evaluert. Nicholson (19) benyttet ulike måleverktøy, noe som kan gi høy risiko for skjevheter. Figur 2 oppsummerer studienes risiko for skjevheter. 
Figur 2: Oppsummering av studienes risiko for systematiske skjevheter

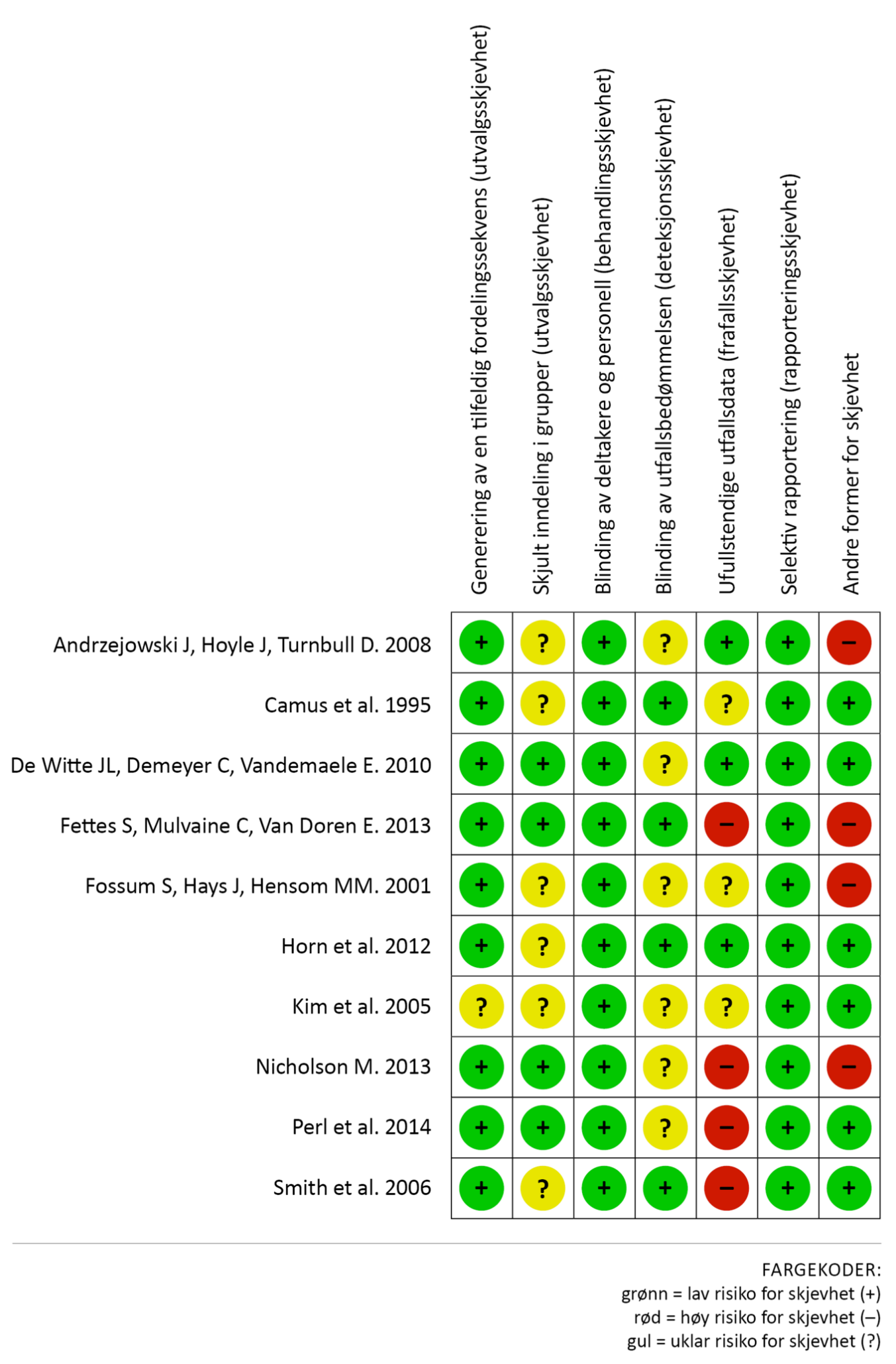

\section{Diskusjon}


Hensikten med studien var å frembringe ny kunnskap om effekten av å bruke varmluftsteppe for å forebygge utilsiktet hypotermi hos elektive operasjonspasienter $\mathrm{i}$ generell anestesi. Hovedfunnene i denne systematiske oversikten indikerer at preoperativ oppvarming med varmluftsteppe har positiv effekt på operasjonspasientenes kjernetemperaturer og kan bidra til å opprettholde normotermi.

Denne studien viser at det er mulig å redusere graden av hypotermi ved hjelp av varmluftsteppe. De ulike utfallene viser de positive tendensene og tyder på at komplikasjoner ved hypotermi kan forebygges.

\section{Effekten av preoperativ oppvarming}

A opprettholde normotermi hos operasjonspasienten kan være utfordrende til tross for at pasienten blir varmet med varmluftsteppe under operasjonen (7). Ifølge Lange (1) er hypotermi en av de mest ukomfortable faktorene som pasienten assosierer med kirurgi. Det er dermed viktig å forebygge hypotermi også for å ivareta pasientens velvære.

Under generell anestesi er pasienten i en spesielt sårbar situasjon og er ikke i stand til å gi uttrykk for sine behov (26). Ved kirurgi og anestesi kan kroppstemperaturen til operasjonspasienten falle med 2-3 grader dersom forebyggende tiltak ikke iverksettes (1). Derfor er det viktig at anestesisykepleieren har kunnskap om konsekvensene av hypotermi og kan forebygge denne tilstanden, slik at pasientsikkerheten ivaretas.

Ansvaret for å sette i verk forebyggende tiltak der komplikasjoner er forventet, er forklart i funksjonsbeskrivelsen for anestesisykepleiere (6). Da hypotermi kan føre til unødige komplikasjoner hos operasjonspasienten, mener vi at forebygging av hypotermi naturlig inngår under krav til faglig forsvarlighet (27).

\section{«Det er viktig å forebygge hypotermi også for å ivareta pasientens velvære.»}


Sessler (28) viser til at aktiv oppvarming forsterker kroppens evne til å opprettholde kjernetemperaturen når den utsettes for varmetap. Man kan derfor tenke at operasjonspasienten kan dra nytte av preoperativ oppvarming med varmluftsteppe. Av de ti studiene vi inkluderte, viser åtte av dem at preoperativ oppvarming med varmluftsteppe har positiv effekt på og kan forebygge hypotermi hos operasjonspasienten $(17,18,20-25)$.

Flertallet av disse studiene viser til signifikante resultater og har lav risiko for skjevheter $(17,18,20,24$, 25). Lav risiko for skjevheter gjør resultatene mer troverdige, da vi i stor grad kan stole på at resultatene gjenspeiler virkeligheten (11). Funnene i de to resterende studiene antyder at preoperativ oppvarming ikke har effekt, men resultatene var ikke statistisk signifikante $(16,19)$.

Disse studiene har dessuten høy risiko for skjevheter, noe som kan tyde på at deres resultater ikke samsvarer med virkeligheten (13). Analysen vår av risiko for skjevheter på tvers av studiene viste at det er lav risiko for skjevheter i de fleste av de sju hovedpunktene. Imidlertid er det to hovedpunkter som skiller seg ut, da de gir størst risiko for skjevheter: «frafallsskjevhet» på grunn av frafall av deltakere fra studien, og «annen skjevhet» på grunn av at ulike måleverktøy er brukt (figur 2).

\section{Faktorer som kan ha påvirket resultatene}

I intervensjonsstudier er det flere faktorer som kan påvirke effekten av et tiltak. Prognostiske faktorer som alder, vekt og sykdom kan i mange tilfeller være med på å påvirke utfallet. Slike faktorer blant deltakerne bør være gjennomsnittlig likt fordelt mellom gruppene (13). Den gjennomsnittlige populasjonsalderen i de inkluderte studiene kan tyde på at det var stor variasjon i deltakernes alder. 
Noen av deltakerne hadde høy KMI, som kan ha hatt positiv innvirkning på resultatene fordi overvektige pasienter er mindre utsatt for varmetap enn slanke pasienter $(3,28)$.

I studiene benyttes ulik intervensjonsvarighet. Lang intervensjonstid gir høyere kjernetemperaturer hos operasjonspasientene. Horn og medarbeidere (18) viser imidlertid at kort intervensjonsvarighet på 10 minutter har signifikant effekt på forebygging av hypotermi. Dette funnet er nytt i forhold til anbefalingene i de Brito Poveda og medarbeidere (9). Det kan forklares med den høye varmestyrken som er anvendt.

De samlete funnene viser en tydelig sammenheng mellom høy varmestyrke og positiv effekt av tiltaket. På bakgrunn av dette ser vi at det er gunstig å anvende høy varmestyrke. Den høye varmestyrken må likevel ikke medføre ubehag for pasientene. Kort oppvarmingstid kan også være mer praktisk og kostnadseffektivt.

Vi mener at oppmerksomheten ikke bare bør være på effektivitet, men på prioritering av pasientsikkerhet og kvalitet. Helsepersonell er pliktige til å sikre kvalitet i arbeidet som utføres, blant annet ved å sette pasienten i sentrum (29).

Flertallet av de inkluderte studiene fortsatte å varme opp aktivt med varmluftsteppe peroperativt. Ut fra funnene i studiene ser vi en tendens til at peroperativ oppvarming har positiv innvirkning på resultatene. Dermed er det naturlig å fortsette pasientoppvarmingen også peroperativt, da pasienten er mest utsatt for varmetap i denne perioden (2).

\section{«De samlete funnene viser en tydelig sammenheng mellom høy varmestyrke og positiv effekt av tiltaket.»}


Et annet sentralt element som kan ha påvirket nøyaktigheten av målingene, er hvilke måleverktøy som er anvendt. Utfallsmålene i studien vår var i hovedsak pasientenes kjernetemperatur, noe som gir det beste bildet av pasientens temperaturstatus (30). Valg av måleverkt øy er omdiskutert i både forskningslitteratur og praksis.

Øretermometer (trommehinnen), Øsofagealt termometer, nasofaryngealt termometer og pulmonalarterietermometer er ansett som pålitelige måleverktøy for å måle kjernetemperaturen $(30,31)$. $\varnothing$ retermometer blir anvendt i flere av de inkluderte studiene $(18,20,21,24)$. Dette måleverktøyet blir ansett som pålitelig dersom det anvendes aurale prober.

Infrarøde termometre blir derimot sett på som unøyaktige måleverktøy (31). I tre av studiene anvendes det infrarøde termometre $(16,21,23)$. De ulike studiene hadde også forskjellige måletidspunkter. Det kan tenkes at dette påvirket resultatene, noe som gjør det vanskelig å sammenlikne studiene.

\section{Metodiske betraktninger}

Denne systematiske litteraturoversikten baseres på RCT. Systematiske litteraturoversikter som inkluderer kvantitativ forskning av god kvalitet, er høyt rangert i evidenshierarkiet (11). For å frembringe ny kunnskap om effekten av preoperativ oppvarming var det nødvendig å utføre et oppdatert artikkels $\varnothing \mathrm{k}$.

Vi utførte et omfattende systematisk artikkels $\varnothing \mathrm{k} \mathrm{i}$ relevante databaser i henhold til anbefalingene til Nasjonalt kunnskapssenter for helsetjenesten, noe som styrker studiens validitet (32). Selv om vi ikke kontaktet de Brito Poveda og medarbeidere (9) for å få deres detaljerte søkestrategi, har vi likevel foretatt et bredt artikkels $\varnothing \mathrm{k}$ som førte til mange treff med relevans for vår problemstilling. 
Vi er imidlertid klar over at det optimale hadde vært også å søke etter upubliserte studier og oversikter, såkalt grå litteratur, og er derfor bevisste på at vi kan ha gått glipp av relevant litteratur. To forfattere uavhengig av hverandre leste gjennom og vurderte kritisk alle artiklene for intern validitet, noe som er med på å fremme objektivitet (11).

Noe annet som styrker studien vår, er at vi anvender et pålitelig verkt øy for å vurdere studienes risiko for systematiske skjevheter, anbefalt av The Cochrane Collaboration (13). Etter vår vurdering gir dette validitetsverktøyet et bedre grunnlag for å kunne gi klare anbefalinger om tiltaket.

For videre forskning anbefaler vi å utføre studier som omhandler barn, eldre over 85 år samt pasienter med ASA-klassifikasjon $>3$. Disse pasientgruppene er mer sårbare for å utvikle hypotermi og er lite beskrevet $\mathrm{i}$ studiene vi innhentet. For å vurdere effekten av preoperativ oppvarming mer generelt bør det utføres studier med preoperativ oppvarming ved flere typer kirurgiske inngrep.

Pasienter som får regionalanestesi, er også utsatt for hypotermi, og det bør derfor utføres flere studier der denne type anestesi praktiseres. Det er av stor betydning at fremtidige studier anvender måleverkt $\varnothing y$ med tilfredsstillende psykometriske egenskaper, og at bruken av verktøyene er konsekvent.

I praksis satses det mer på karbonfiberteknologi som oppvarmingsmetode, men det finnes lite forskning på dette tiltaket. Fordelene med karbonfiberteknologi som oppvarmingsmetode må derfor unders $\varnothing$ kes nærmere.

\section{Kliniske implikasjoner}


Vår systematiske litteraturoversikt identifiserer kun fordeler ved å tilby operasjonspasienten preoperativ oppvarming med varmluftsteppe. Foruten tidsbruk og $\varnothing$ konomi påviste vi ingen ulemper eller uheldige bivirkninger knyttet til tiltaket. Tidligere oversikter som benytter andre typer oppvarmingsmetoder, støtter dette funnet $(9,10)$.

\section{«Foruten tidsbruk og økonomi påviste vi ingen ulemper eller uheldige bivirkninger knyttet til tiltaket.»}

På grunnlag av resultatene anbefaler vi på det sterkeste at anestesisykepleiere tar i bruk preoperativ oppvarming med varmluftsteppe som forebyggende tiltak. Vi anbefaler å benytte varmluftsteppe med høy varmestyrke, over 40 grader, og med intervensjonsvarighet fra 10 til 30 minutter. Spesielt anbefaler vi tiltaket til voksne pasienter som skal gjennomgå elektive inngrep i generell anestesi, med operasjonstid over 30 minutter.

\section{Konklusjon}

Å opprettholde normotermi hos operasjonspasienten er viktig for å hindre at anestesirelaterte komplikasjoner oppstår, og for å sikre kvalitet i arbeidet som utføres. Funnene våre viser tydelig at det finnes flere faktorer som kan ha ført til et fall i pasientens kjernetemperatur. Likevel indikerer resultatene i denne systematiske oversikten at preoperativ oppvarming med varmluftsteppe har signifikant effekt på forebygging av utilsiktet hypotermi hos voksne elektive operasjonspasienter i generell anestesi. 
Resultatene antyder også at oppvarming av pasienten med fordel kan fortsette peroperativt. Vi mener at denne systematiske litteraturoversikten kan gi et balansert bilde av hva forskning har vist innen preoperativ oppvarming med varmluftsteppe og forebygging av hypotermi. I tillegg mener vi at studien er en god kunnskapskilde når helsepersonell skal ta beslutninger i praksis vedrørende preoperativ oppvarming.

Takk til bibliotekarene Elisabeth Hundstad Molland ved Stavanger universitetssjukehus og Grete Mortensen ved Universitetet $i$ Stavanger for bidrag i forbindelse med varrt systematiske artikkelsøk. Vi vil også takke Lillebeth Larun ved Nasjonalt kunnskapssenter for helsetjenesten for gode råd underveis.

\section{Referanser}

1. Lange KHW. Anæstesiologiske komplikationer. I: Rasmussen LS, Steinmetz J, red. Anæstesi. København: FADLs Forlag; 2014. s. 295-318.

2. Bozimowski G. Clinical monitoring II: Respiratory and metabolic systems. I: Nagelhout JJ, Plaus KL, red. Nurse Anesthesia. St. Louis, Missouri:

Saunders/Elsevier; 2014. s. 313-24.

3. Berg T, Hagen O. Forebygging og behandling av anestesirelaterte komplikasjoner. I: Hovind IL, red. Anestesisykepleie. Oslo: Akribe; 2011. s. 280-307.

4. Nasjonal Pasientsikkerhetskampanje. Sjekkliste for trygg kirurgi og postoperative sårinfeksjoner [Internett]. Oslo:Helsedirektoratet; 2013 [sitert 10.05.2016]. Tilgjengelig fra:

http://www.pasientsikkerhetsprogrammet.no/no/I+tryg ge+hender/Innsatsomr\%C3\%A5der/trygg-kirurgi-medoppmerksomhet-p\%C3\%A5-postoperatives\%C3\%A5rinfeksjoner.

5. Bruun AMG. Anestesisykepleierens kompetanse. I: Hovind IL, red. Anestesisykepleie. Oslo: Akribe AS; 2011. s. 19-39. 
6. Anestesisykepleiernes Landsgruppe av NSF. Funksjonsbeskrivelse for anestesisykepleiere [Internett]. Oslo: Anestesisykepleiernes Landsgruppe av NSF; 2014 [sitert 01.05.2016]. Tilgjengelig fra: https://www.nsf.no/Content/112221/Funksjonsbeskrivel se\%20\%20for\%20anestesisykepleiere,\%2orevidert_2.

7. Hooper VD, Chard R, Clifford T, Fetzer S, Fossum $\mathrm{S}$, Godden B et al. ASPAN's evidence-based clinical practice guideline for the promotion of perioperative normothermia. Journal of PeriAnesthesia Nursing. 2009;24(5):271-87. DOI: 10.1016/j.jopan.2010.10.006.

8. Galvao CM, Liang Y, Clark AM. Effictiveness of cutaneous warming systems on temperature control: meta-analysis. Journal of Advanced Nursing. 2010;66(6):1196-206. DOI: 10.1111/j.13652648.2010.05312.x.

9. de Brito Poveda V, Clark AM, Galvao CM. A systematic review of the effectiveness of prewarming to prevent perioperative hypothermia. Journal of Clinical Nursing. 2012;22:906-18. DOI: 10.1111/j.13652702.2012.04287.x.

10. Roberson MC, Dieckmann LS, Rodriguez RE, Austin PN. A review of the evidence for active preoperative warming of adults undergoing general anesthesia. AANA Journal. 2013;81(5):351-6.

11. Polit D, Beck CT. Nursing research: Generating and assessing evidence for nursing practice. Philadelphia: Lippincott Williams \& Wilkins; 2012.

12. Liberati A, Altman D, Tetzlaff J, Mulrow C, Gøtzsche P, Ioannidis J, et al. The PRISMA statement for reporting systematic review and meta-analyses of studies that evaluate health care interventions: Explanation and elaboration. PLoS Medicine. 2009;6(7):1-28. DOI: 10.1371/journal.pmed.1000100. 
13. Higgins JPT, Altman DG. Assessing risk of bias in included studies. I: Higgins JPT, Green S, red. Cochrane handbook for systematic reviews of interventions England: The Cochrane Collaboration; 2008. s. 187-241.

14. Boland A, Cherry MG, Dickson R. Doing a systematic review : A student's guide. Thousands Oaks, California: Sage; 2014.

15. Nasjonalt kunnskapssenter for helsetjenesten. Sjekklister for vurdering av forskningsartikler [Internett]. Oslo: Nasjonalt kunnskapssenter for helsetjenesten; 2014 [sitert 01.05.2016]. Tilgjengelig fra:

http://www.kunnskapssenteret.no/verktoy/sjekklisterfor-vurdering-av-forskningsartikler. Ny, oppdatert versjon finnes tilgjengelig fra: https://www.fhi.no/globalassets/kss/filer/filer/verktoy/sj ekkliste-rct-2014.pdf.

16. Fettes S, Mulvaine M, Van Doren E. Effect of preoperative forced-air warming on postoperative temperature and postanesthesia care unit length of stay. AORN Journal. 2013;97(3):323-9. DOI:

10.1016/j.aorn.2012.12.011.

17. Perl T, Peichl LH, Reyntjens K, Deblaere I, Zaballos JM, Brauer A. Efficacy of a novel prewarming system in the prevention of perioperative hypothermia. A prospective, randomized, multicenter study. Minerva Anestesiologica. 2014;80(4):436-43.

18. Horn EP, Bein B, Bohm R, Steinfath M, Sahili N, Hocker J. The effect of short time periods of preoperative warming in the prevention of peri-operative hypothermia. Anaesthesia. 2012;67(6):612-7. DOI: 10.1111/j.1365-2044.2012.07073.x.

19. Nicholson MA. Comparison of warming interventions on the temperatures of inpatients undergoing colorectal surgery. AORN Journal. 2013;97(3):310-22. DOI: 10.1016/j.aorn.2012.12.018. 
20. Camus Y, Delva E, Sessler DI, Lienhart A. Preinduction skin-surface warming minimizes intraoperative core hypothermia. Journal of Clinical Anesthesia. 1995;7:384-8. DOI: 10.1016/09528180(95)00051-I.

21. Fossum S, Hays J, Henson MM. A comparison study on the effects of prewarming patients in the outpatient surgery setting. Journal of PeriAnesthesia Nursing. 2001;16(3):187-94. DOI:

10.1053/jpan.2001.24039.

22. Kim JY, Shinn H, Oh YJ, Hong YW, Kwak HJ, Kwak YL. The effect of skin surface warming during anesthesia preparation on preventing redistribution hypothermia in the early operative period of off-pump coronary artery bypass surgery. European Journal of Cardio-thoracic Surgery. 2006;29:343-7. DOI: 10.1016/j.ejcts.2005.12.020.

23. Andrzejowski J, Hoyle J, Eapen G, Turnbull D. Effect of prewarming on post-induction core temperature and the incidence of inadvertent perioperative hypothermia in patients undergoing general anesthesia. British Journal of Anesthesia. 2008;101(5):627-31. DOI: 10.1093/bja/aen272.

24. De Witte JL, Demeyer C, Vandemaele E. Resistiveheating or forced-air warming for the prevention of redistribution hypothermia. Anaesthesia Analgesia. 2010;110(3):829-33. DOI: 10.1213/ANE.obo13e3181cb3ebf.

25. Smith C, Sidhu R, Lucas L, Mehta D, Pinchak A. Should patients undergoing ambulatory surgery with general anesthesia be actively warmed? The Internet Journal of Anesthesiology. 2006;12(1):1-10. Tilgjengelig fra: http://print.ispub.com/api/o/ispub-article/10591 (nedlastet 01.05.2016).

26. Nortvedt P. Etiske utfordringer. I: Hovind IL, red. Anestesisykepleie. Oslo: Akribe; 2011. s. 51-61. 
27. Lov 2. juli 1999 nr. 64 om helsepersonell m.v.

(helsepersonelloven). Tilgjengelig fra:

https://lovdata.no/dokument/NL/lov/1999-07-02-64?

$\mathrm{q}=$ helsepersonelloven (nedlastet 01.05.2016).

28. Sessler DI. Perioperative heat balance.

Anesthesiology [Internett]. 2000; 92(2):578-96 [sitert

01.05.2016]. Tilgjengelig fra:

http://anesthesiology.pubs.asahq.org/article.aspx?

articleid $=1946305$.

29. Meld. St. nr. 10 (2012-2013). God kvalitet - trygge tjenester - Kvalitet og pasientsikkerhet i helse- og omsorgstjenesten. Oslo: Helse- og omsorgsdepartementet; 2012. Tilgjengelig fra: https://www.regjeringen.no/no/dokumenter/meld-st10-20122013/id709025/?ch=1\&q= (nedlastet 01.05.2016).

30. Sessler DI. Temperature monitoring and perioperative thermoregulation. Anesthesiology. 2008;109(2):318-38. DOI: 10.1097/ALN.obo13e31817f6d76.

31. Lenhardt R. Monitoring and thermal management best practices \& research. Clinical Anaesthesiology. 2003;17(4):569-80. DOI: 10.1016/S1521-6896(03)00048X.

32. Nasjonalt kunnskapssenter for helsetjenesten. Handbok for Nasjonalt kunnskapssenter for helsetjenesten: Slik oppsummerer vi forskning. Oslo: 2013. Tilgjengelig fra: http://www.kunnskapssenteret.no/verktoy/slikoppsummerer-vi-forskning (nedlastet 01.05.2016). Ny, oppdatert versjon finnes tilgjengelig fra:

https:/www.fhi.no/globalassets/kss/filer/filer/verktoy/2 O15_handbok_slik_oppsummerer_vi_forskning.pdf. 